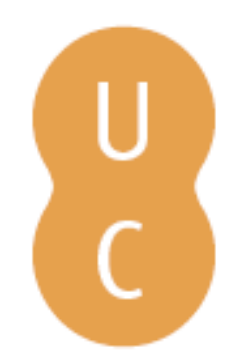

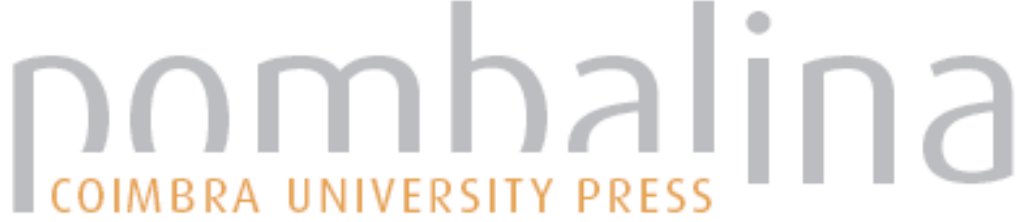

\section{Understanding the changing fire environment of south-west Western Australia}

\author{
Autor(es): $\quad$ McCaw, Lachlan
}

Publicado por: Imprensa da Universidade de Coimbra

URL

persistente: URI:http://hdl.handle.net/10316.2/44534

DOI: $\quad$ DOI:https://doi.org/10.14195/978-989-26-16-506_17

Accessed : $\quad$ 26-Apr-2023 11:58:25

A navegação consulta e descarregamento dos títulos inseridos nas Bibliotecas Digitais UC Digitalis, UC Pombalina e UC Impactum, pressupõem a aceitação plena e sem reservas dos Termos e Condições de Uso destas Bibliotecas Digitais, disponíveis em https://digitalis.uc.pt/pt-pt/termos.

Conforme exposto nos referidos Termos e Condições de Uso, o descarregamento de títulos de acesso restrito requer uma licença válida de autorização devendo o utilizador aceder ao(s) documento(s) a partir de um endereço de IP da instituição detentora da supramencionada licença.

Ao utilizador é apenas permitido o descarregamento para uso pessoal, pelo que o emprego do(s) título(s) descarregado(s) para outro fim, designadamente comercial, carece de autorização do respetivo autor ou editor da obra.

Na medida em que todas as obras da UC Digitalis se encontram protegidas pelo Código do Direito de Autor e Direitos Conexos e demais legislação aplicável, toda a cópia, parcial ou total, deste documento, nos casos em que é legalmente admitida, deverá conter ou fazer-se acompanhar por este aviso.

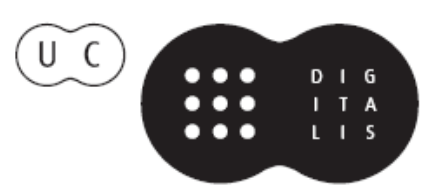




\section{ADVANCES IN}

\section{FOREST FIRE RESEARCH}

\section{8}

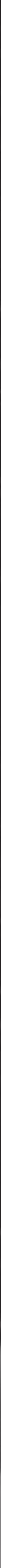




\title{
Understanding the changing fire environment of south-west Western Australia
}

\author{
Lachlan McCaw \\ Department of Biodiversity, Conservation and Attractions, Manjimup 6258, Western Australia \\ \{lachie.mccaw@dbca.wa.gov.au\}
}

\begin{abstract}
Fire environment is the resultant effect of factors that influence the ignition, behaviour and extent of fires in a landscape. This paper synthesises information available from a variety of sources to evaluate evidence for changes over the past three decades in components of the fire environment for south-west Western Australia including climate and weather, fuel, and ignition. A combination of land use, socio-economic and organisational factors has resulted in more widespread extent of lands unburnt for several decades, increasing the risk of high severity fires with adverse impacts on the community and environment. The Mediterranean type climate of the region has become warmer and significantly drier since the 1970s, with associated changes in the timing and duration of the traditional fire season. Lightning ignition has become more common, either as result of greater summer thunderstorm activity or increased opportunity for ignitions to sustain and spread. Increased lightning ignition is significant because of the dis-proportionately large proportion of area burnt by lightning caused fires in SWWA. Adapting to a changing fire environment has implications for all aspects of the fire management business, and a variety of new products and services are available to inform fire managers about temporal and spatial trends in components of the fire environment.
\end{abstract}

Keywords: fire environment, climate, eucalypt forest, Mediterranean ecosystems

\section{The fire environment concept}

Fire environment is the resultant effect of factors that influence the ignition, behaviour and extent of fires in a landscape. Countryman (1966) defined the fire environment as comprising the fuel, topographic and airmass factors that influence or modify the inception, growth and behaviour of fire. In this paper ignition is also considered a component of the fire environment for the reason that the cause, frequency, spatial pattern and timing of ignition are characteristic of a region and a period of time. The fire environment provides a setting within which a variety of fire regimes defined by season, frequency and intensity of burning are enacted in response to a combination of chance events and human actions.

The focus of this paper is the south-west corner of Western Australia (SWWA), a region characterised by ancient landscapes, a Mediterranean type climate and a unique flora and fauna that have evolved in prolonged isolation from other parts of the Australian continent. Defining features of region include the densely populated and extensively cleared Swan coastal plain, a relatively continuous zone of open eucalypt forest comprising State forest and various categories of conservation reserve, and an extensively cleared dryland farming zone known as the Western Australian Wheatbelt (Fig. 1). Public lands occupy about $6 \mathrm{M}$ ha of this region in the form of national park, multiple-use State forest and other categories of reserved land. The eastern margin of the Wheatbelt interfaces with a vast, remote and sparsely populated semi-arid zone where mining and pastoralism are the dominant economic activities. Much of this area remains as unallocated crown land, with a renewed emphasis on the role of traditional owners as custodians and managers of the land. 


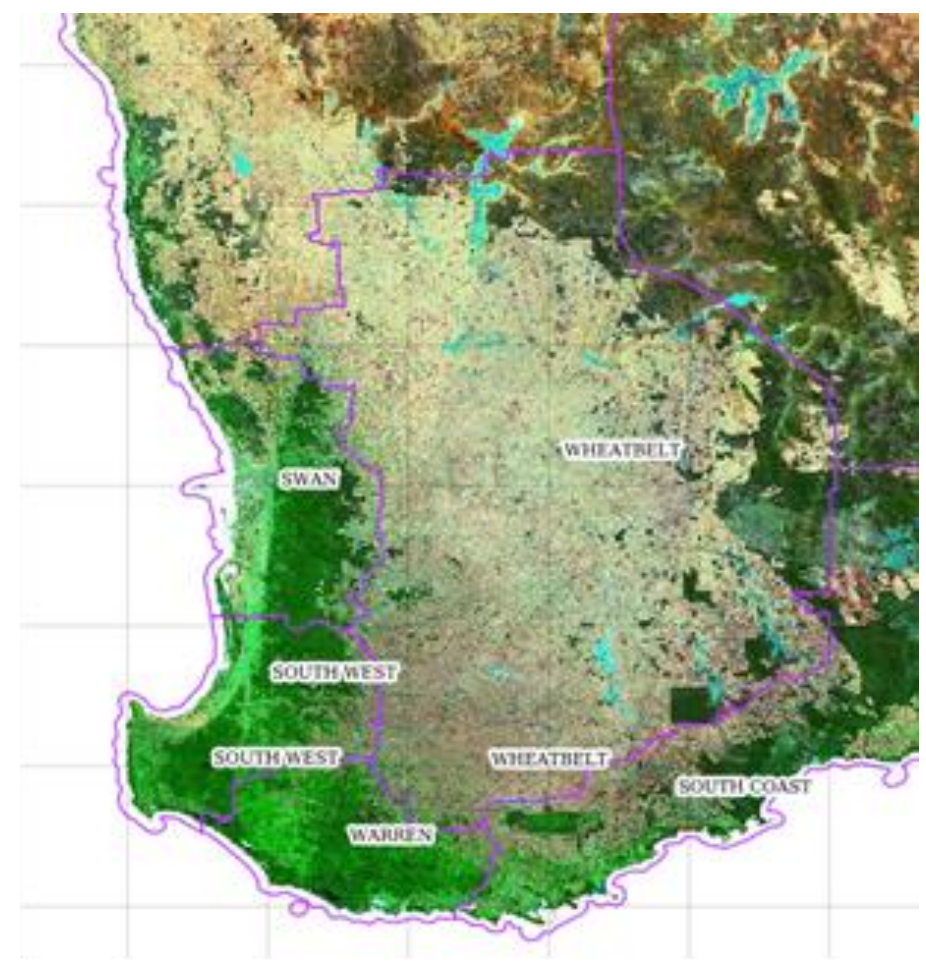

Figure 1 - Satellite image showing broad land use zones within south-west Western Australia. Names indicate regional administrative areas for management of public land by the Department of Biodiversity, Conservation and Attractions Western Australia.

Essential features of the fire environment of SWWA have been described by McCaw and Hanstrum (2003). Weather factors exerting a significant influence on the fire evironment include coastal sea breezes, strong dry winds blowing from the continental interior, abrupt wind changes associated with pre-frontal troughs, and periodic incursion of tropical cyclones south of latitude $30^{\circ} \mathrm{S}$. The 15 year period since the publication of McCaw and Hanstrum (2003) has seen a reduction in the area burnt by planned (prescribed) fire and a substantial increase in the area burnt by uplanned bushfire across SWWA, including a number of large and destructive fires (eg. Ferguson 2016). This period has also seen significant advances in numerical weather prediction that have allowed temporal and spatial patterns of weather and other environmental variables (eg. soil dryness) to be analysed independently of the observational network which is limited across much of SWWA. Re-analysis data now provide a robust method for establishing climatological norms for meteorological variables and derived values of fire danger and potential fire behaviour (Jones et al. 2009, Dowdy and Pepper 2018).

The intent of this paper is to synthesise information available from a variety of sources and products to evaluate evidence for change over the past three decades in each of the core components of the fire environment:

- climate and weather

- ignition,

- the landscapes in which fires are burning.

\section{Fire and planned burning activity in SWWA}

Over the 15 year period from 2002-2017 the Department of Biodiversity, Conservation and Attractions (and previous public land management agencies) responded to more than 7000 bushfires on public land across SWWA (Fig. 2). The total number of fires that occurred during this period would 
be considerably greater once fires on private property attended by volunteer brigades and fires in gazetted fire districts attended by career Fire and Rescue personnel are accounted for. Around half of the fires on public land were lit deliberately, with lightning being the second largest cause of ignition (1200 fires). Lightning ignition was the dominant cause of area burnt, accounting for $1.43 \mathrm{M}$ ha of the total $1.94 \mathrm{M}$ ha burned by bushfires during the period. During this period bushfires ignited by lightning burnt around $23 \%$ of the public land in SWWA.
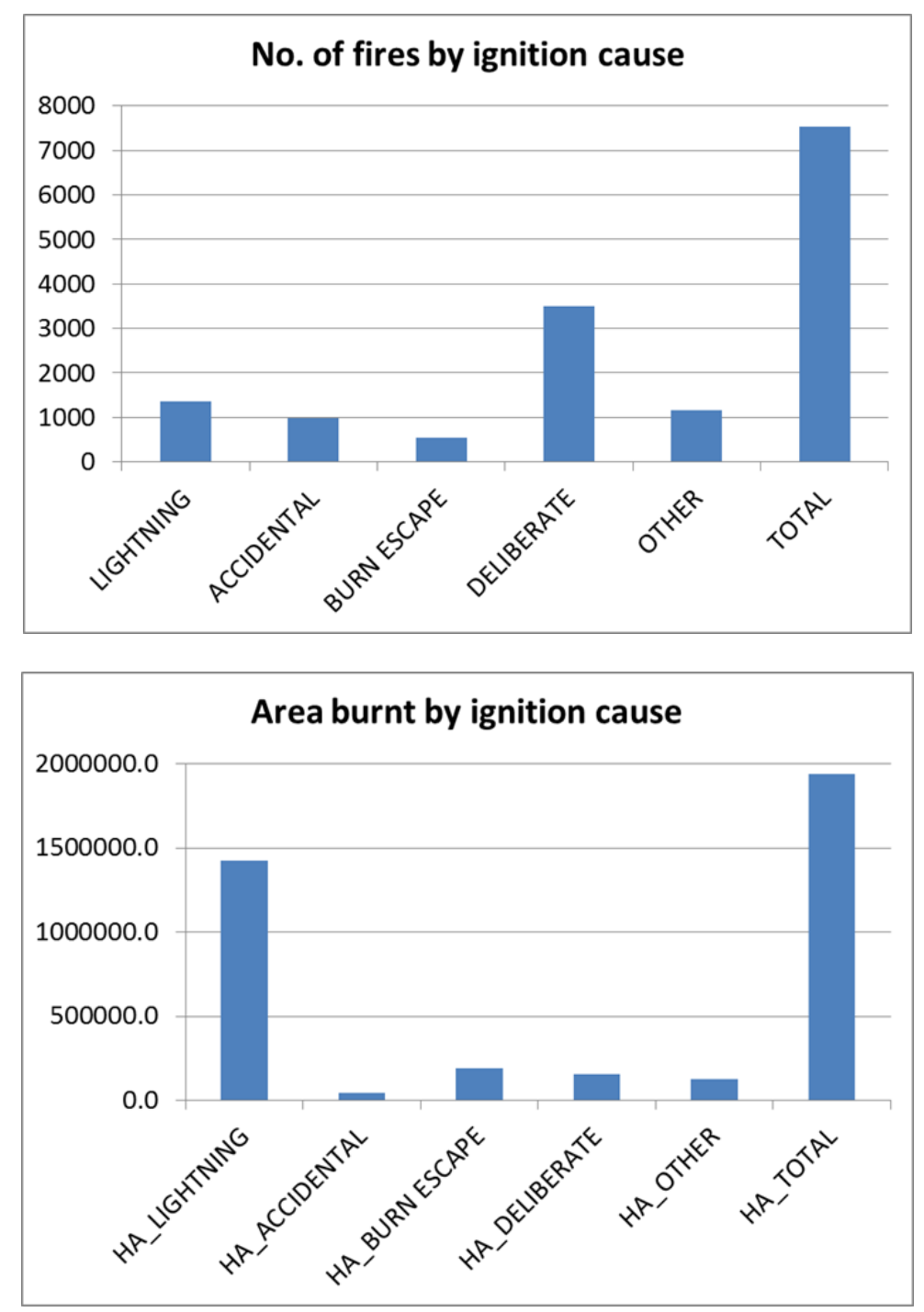

Figure 2 - Number of bushfires (upper panel) and area burnt by bushfires (lower panel) categorised by ignition cause for the period 2002-2017. Data extracted from fire reports for SWWA regional administrative areas shown in Fig. 1.

Prescribed fire has been used extensively in the predominantly forested regions of SWWA since the late 1950s to manage fuels and achieve a range of land management objectives (Burrows and McCaw 2013). Following a period of relatively stable planned burning activity through the 1980s and 1990s the period since 2000 has seen increased variability and an overall reduction in the scale of the planned burning program (Fig. 3). 


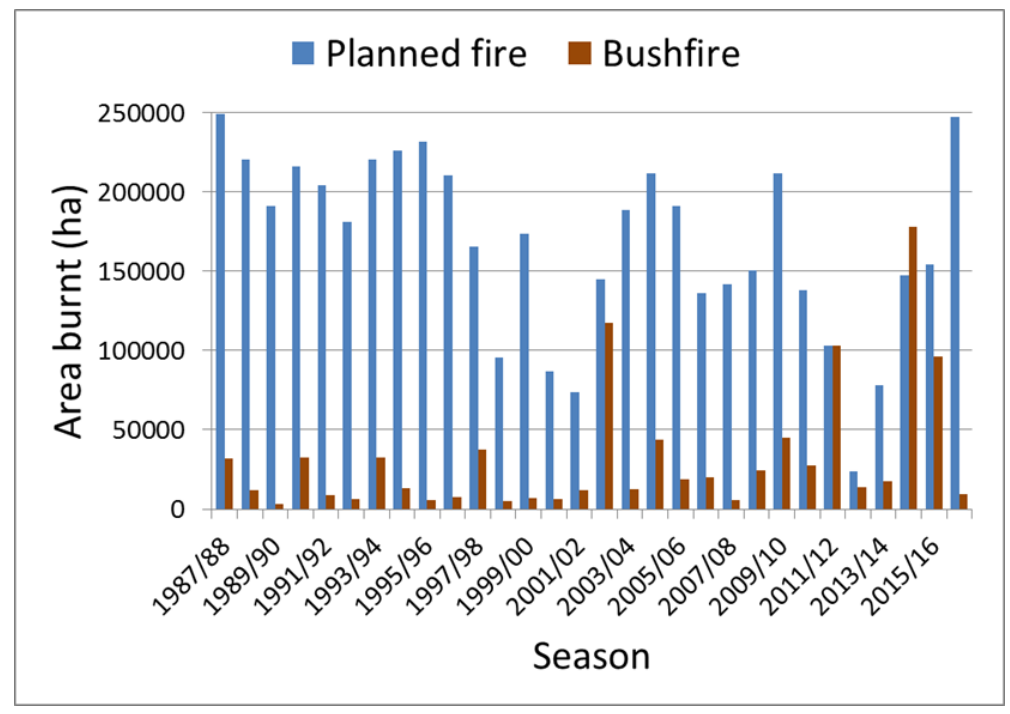

Figure 3 - Trend in area burnt by planned and unplanned fire for Swan, South West and Warren regional administrative areas for the period 1987-2017.

In the predominantly forested regions bushfire activity exhibited a relatively stable pattern during the 15 year period from 1987 to 2002 with less than 10000 ha burnt in most years, and more active bushfire seasons every third or fourth with up to 40000 ha burnt (Fig. 3). However, the 2002/03 bushfire season marked a turning point with a major increase in the area burnt by bushfire, mostly due ignition by lightning. The trend of increased area burnt by bushfire has been maintained for the following 15 years with notably large areas burnt in 2011/12, 2014/15 and 2015/16. Damaging bushfires requiring an extended suppression response also occurred in Swan Region in 2005, 2007 and 2009.

Reduction in the extent of prescribed burning after 2000 would partially explain the increased area burnt by bushfire, with a study by Boer et al. (2009) demonstrating a strong inverse relationship between the extent of prescribed burning and unplanned fire in the Warren Region over a period of five decades. A variety of factors have contributed to the reduced area of prescribed burning achieved since 2000 . These factors include greater sensitivity to smoke by the community and the wine industry, constraints on burning imposed by Government following significant escapes from prescribed burning in spring 2011, temporary restrictions on operations arising from a fatal burn-over incident during a bushfire in spring 2012 and increasing complexity of managing prescribed fire in landscapes fragmented by mining and intensive timber harvesting. Burning opportunities in the tall forests of the Warren Region (Fig. 1) have been foregone because of the need to deploy personnel and equipment to bushfire suppression operations in other parts of the south-west. In particular, this has impacted on the achievement of prescribed burning in tall forests dominated by karri (Eucalyptus diversicolor) where conditions suitable for burning typically occur in early summer (December, January), coinciding with the peak period of bushfire activity in other parts of SWWA.

\section{Land use}

Land use activities have a major influence on the condition of vegetation and the ability to manage fuels through planned burning in a safe and cost-effective way. Bauxite mining has been underway on State forest lands in the Swan and South West regions for around 50 years and is an important economic activity for the state. A total of about 25000 ha have been cleared to date of which 20000 ha have been rehabilitated with trees and shrubs native to the local area. Since only 20-30 percent of each catchment is cleared for mining, the total area impacted is about three to five times larger (75000- 
100000 ha, Batini 2016). Fragmentation of the landscape caused by mining operations (Fig. 4) means that planned burning is deferred for an extended period while mining takes place, and then as the rehabilitated pits are left to grow on to a stage where the vegetation becomes fire tolerant. Fuel management of residual native forest within the mining envelope is technically possible but the complexity, risk and unit cost of operations is much higher than in undisturbed forest landscapes. In practice, the combined effect of these factors has led to prescribed fire being excluded from large areas of forest for several decades resulting in high connectivity of heavy fuels at the landscape scale. This situation was exemplified by the 2016 Waroona bushfire which exhibited two violent pyro-convective events including a massive convective plume that developed within 12 hours of ignition (Ferguson 2016, Peace et al. 2018). Lightning activity associated with this plume ignited further fires that caused unexpectedly rapid spread overnight. Atmospheric conditions were clearly favourable for convective activity, with long unburnt fuels on steep slopes and extreme dryness of the fine and woody fuels contributing to intense fire behaviour.

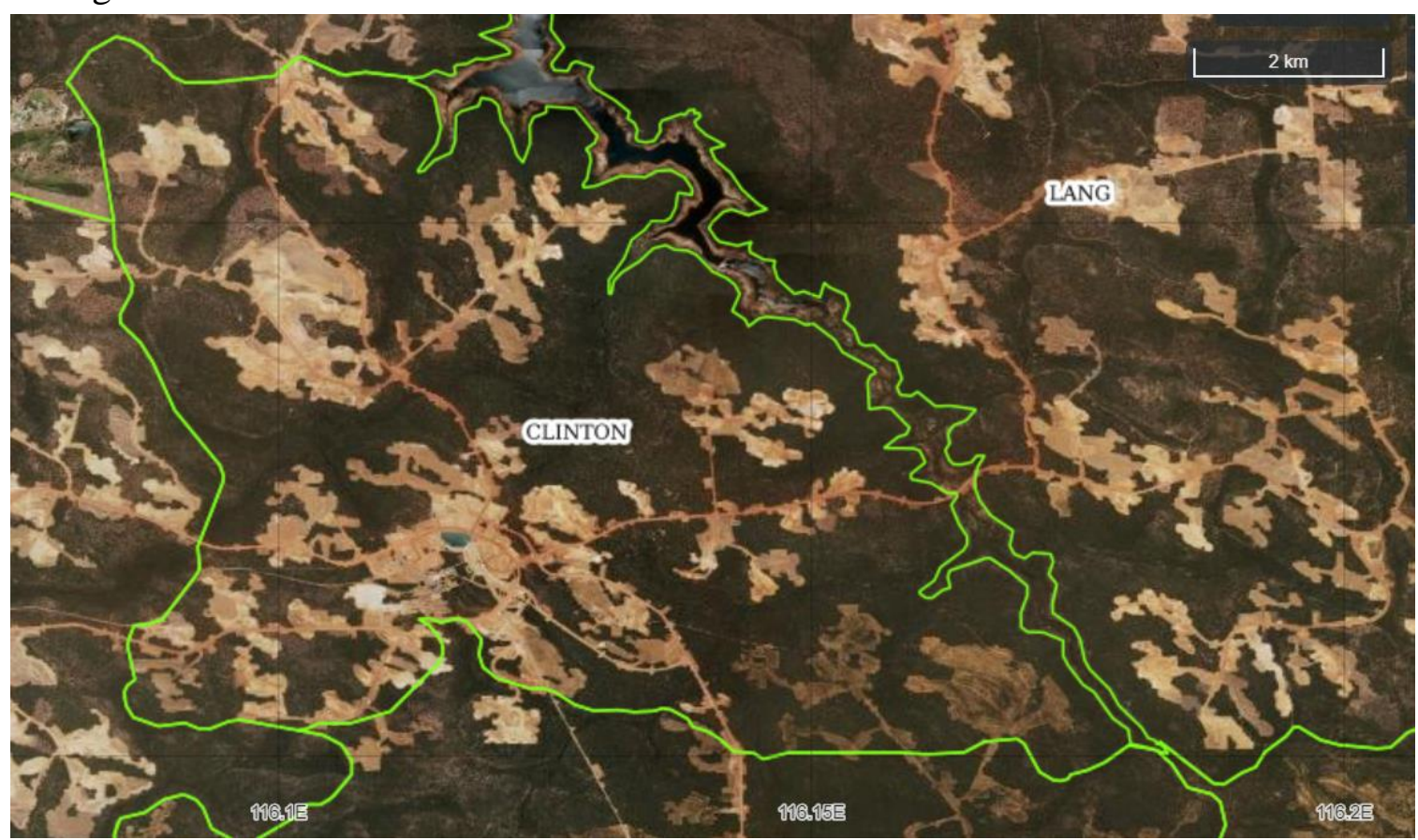

Figure 4 - Aerial image showing the extent of current (2017) bauxite mining operations on State forest in Clinton and Lang forest blocks in the Swan Region. Green lines show the management boundary of each forest block. Note the scale bar shown at top right of image.

Similar issues exist in areas of forest that have been subject to intensive timber harvesting and regeneration of even-aged stands. Forest managers must consolidate young regeneration into management units of sufficient scale and homogeneity to allow cost effective use of planned burning for fuel management. This may require multiple ignitions over a period of weeks, possibly longer, to achieve desired burning conditions for stands in different developmental stages.

\section{Trends in climate, weather and fuel dryness}

The Mediterranean type climate of SWWA results in a prolonged dry period during the Austral summer and autumn with the fire season typically extending from October to May in most years. Since the 1970s SWWA has undergone a persistent drying trend that is most pronounced along the west coast where annual rainfall has declined by 20 to $40 \mathrm{~mm}$ per decade (Bureau of Meteorology 2018). Rainfall decline has been predominantly during the autumn and early winter period, and days of very heavy rainfall have become less common (Indian Ocean Climate Initiative 2012). Notably dry years 
include 2006, 2010 and 2015. A warming trend is also evident from the 1970s onwards, becoming persistent from the mid-1990s with very few below normal summers to offset the trend (Fig. 5).

Summer mean temperature anomaly - Southwestern Australia (1910-2016)

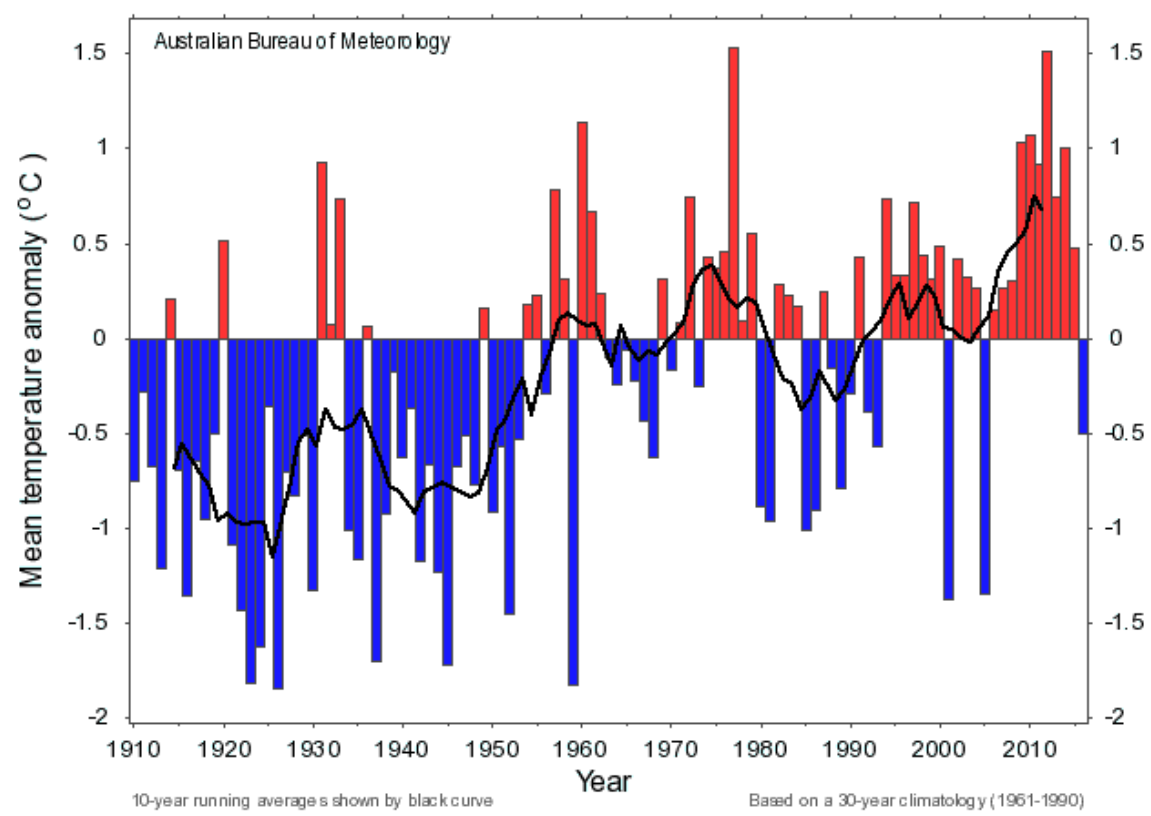

Figure 5 - Trend in summer mean temperature anomaly 1910-2016.

Source: Bureau of Meteorology (www.bom.gov.au)

Consistent with the trend to a warmer and drier climate Dowdy (2018) reported a significant increase in seasonal mean values of the Forest Fire Danger Index (FFDI; McArthur 1967) during winter (JJA) and spring (SON) across most of SWWA, particularly for the period from 2000-2016. No long term trend in mean FFDI was detected for the peak bushfire season spanning summer (DJF) and autumn (MAM). The number of days exceeding the $90^{\text {th }}$ percentile value for the 56 year study period also increased significantly during spring, with some evidence of more localised increases during summer particulalry along the Indian Ocean coast. This signal was stronger for the period 2000-2016 than for earlier periods. The trends identified by Dowdy (2018) point to a lengthening of the bushfire season more than an intensification of mean fire danger during the peak summer months.

Other empirical evidence of a lengthening of the fire season is provided by Soil Dryness Index (SDI; Mount 1972, Burrows 1987) which is a numerical value derived from daily rainfall and maximum temperature. The SDI reflects the dryness of soil, deep layers of surface fuel, woody fuel and some components of living vegetation. It is one of several indices used to guide selection of conditions for prescribed burning and to indicate the potential severity and difficulty of suppression of forest fires. Typically, the SDI rises rapidly during spring with the onset of warm dry weather, reaches a peak during early autumn and then falls, often abruptly, with the arrival of the strong cold fronts in mid autumn. Operational guidance in the Forest Fire Behaviour Tables for Western Australia (Sneeuwjagt and Peet 1985) recommends a fall of 400 units ( $\mathrm{mm} \times 10)$ of SDI prior to commencement of prescribed burning in autumn. Based on SDI values calculated for Manjimup, a location broadly representative of the Warren Region, the median date for a fall of 400 units has shifted almost three weeks later into autumn since the decade 1975-84 (Table 1). This trend has implications for the window of suitable weather conditions available for autumn burning, as deep litter and woody fuel remain dry later into autumn while other factors that also determine the success of prescribed burning, particularly solar angle and day length, remain unchanged. In order to retain a realistic window of opportunity for autumn prescribed burning operational guidance has been revised to adopt a more riskbased approach where the consequences of burning at various values of SDI are specified in relation 
to the likelihood of achievement of burn objectives. This approach permits fire practitioners to make an informed decision based on risk and likely outcome.

Table 1 - Date for an autumn fall of 400 units (mm $x$ 10) in the Soil Dryness Index at Manjimup by decadal periods from 1975 to 2014

\begin{tabular}{cccc}
\hline Period & $\begin{array}{c}\text { Median date for } 400 \\
\text { unit fall }\end{array}$ & $\begin{array}{c}\text { Earliest date for } 400 \\
\text { unit fall }\end{array}$ & $\begin{array}{c}\text { Latest date for } 400 \\
\text { unit fall }\end{array}$ \\
\hline $1975 / 84$ & 25 April & 3 April & 28 May \\
$1985 / 94$ & 6 May & 1 March & 23 May \\
$1995 / 04$ & 13 May & 14 April & 31 May \\
$2005 / 14$ & 8 May & 1 April & 26 May \\
\hline
\end{tabular}

Recent developments in process based hydrological modelling have assisted in understanding and interpreting trends at the landscape scale. The Australian Landscape Water Balance is a daily $0.05^{\circ}$ grid-based, distributed water balance model that simulates the flow of water through the landscape from rainfall entering the grid cell, through the vegetation and soil moisture stores, and then out of the grid cell through evapotranspiration, runoff and deep drainage to the groundwater (Smith et al. 2015). The AWRA-L model provides values for three soil layers (upper: $0-10 \mathrm{~cm}$, lower: $10-100 \mathrm{~cm}$, and deep: 1-6 m) expressed either as the actual percentage of available water content or as a percentile value relative to a calibration period from 1911-2016. Figure 6 shows the trend in annual deep soil moisture over the period 2005-2017 for the Warren River catchment which includes the town of Manjimup. During this period deep soil moisture declined below the 1 percentile value for the historical reference period in 2010 , and remained below the $10^{\text {th }}$ percentile value until the winter of 2016.

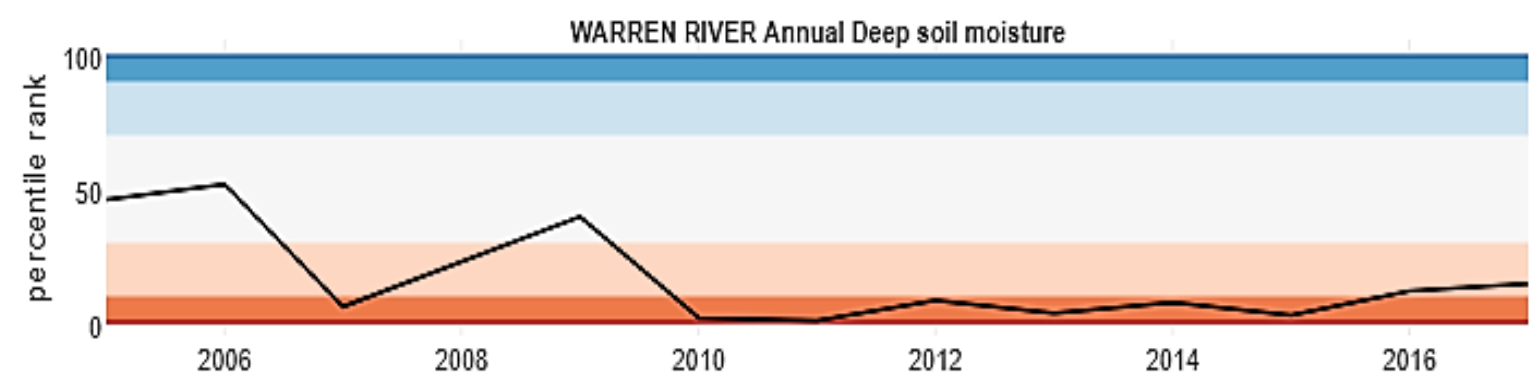

Figure 6 - Trend in annual deep soil moisture over the period 2005-2017 for the Warren River catchment expressed as a percentile for the calibration period 1911-2016. Orange band represents values below the 10th percentile and the red band values are below 1 percentile. Source: Bureau of Meteorology (www.bom.gov.au/water/landscape/)

Drier landscapes have important implications for fire management. Lack of moisture recharge means that swamps and riparian vegetation are less likely to act as temporary barriers to fire spread in spring and early summer. Peat soils, which are common on the coastal plain, may ignite and burn for extended periods with adverse consequences for smoke emissions and ecological values including plant and animal species that rely on peat swamps as habitat.

Lack of moisture recharge also means that woody fuels ignite more readily and at an earlier time in the fire season. In open eucalypt forests in SWWA woody fuel loads consisting of stumps and fallen logs will typically be in the range from 75-100 $\mathrm{tha}^{-1}$, more than four times the equilibrium fine fuel load of 10-15 $\mathrm{t} \mathrm{ha}^{-1}$ of dead leaves and twigs (McCaw 2011). Under dry summer conditions at least half this woody material will burn away representing up to four times the quantity of fine fuel consumed (Hollis et al. 2016). This increase in total heat release potentially adds to convective activity 
above the fire, and increases direct thermal effects on soil and vegetation leading to higher fire severity. Total emissions to the atmosphere will also be greater, with a higher proportion originating from smouldering combustion. Mop-up operations to extinguish burning logs and dead trees also take longer and are more costly when a large proportion of the woody fuel is ignited.

\section{Trends in lightning ignition}

Lightning is an important cause of unplanned fires in SWWA causing 1200 ignitions on public land in the period from 2002 to 2017 (Fig. 2). Fires ignited by lightning burned an area of 1.43 Million ha during this period, exceeding the total area burned by all other causes combined. Lightning caused fires account for a dis-proportionately large percentage of area burnt because of their occurrence in large spatial and temporal clusters, and in remote areas not otherwise prone to ignition by human causes.

Analysis of reliable fire report data over a 41 year period reveal a statistically significant increase in the number of lightning ignitions for the Warren Region particularly from 2002 onwards (Fig. 7, Bates et al. in press). The amplitude and length of the seasonal cycle also appear to have changed, with an increase in lightning ignition during October and November.

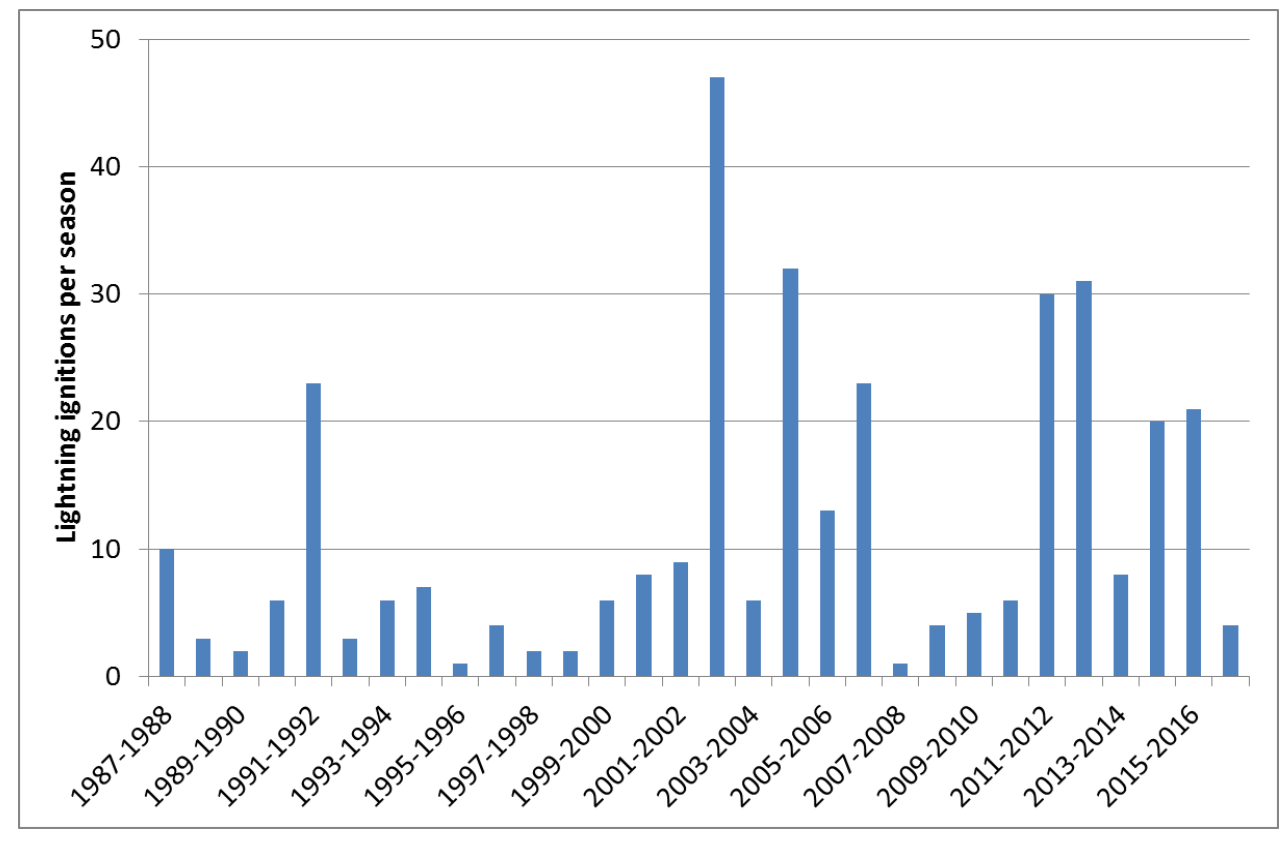

Figure 7 - 30 year trend in lightning ignition for the Warren Region, SWWA.

Ongoing investigations seek to establish the relative influence of changes in thunderstorm activity and increased opportunity for ignitions to sustain and spread in a drier climate. A climatological analysis of the Continuous Haines Index derived from the ERA-Interim reanalysis indicated little evidence of change over the period 1979-2016. The role of regional scale climate drivers is also being investigated to determine whether seasonal lightning activity can be forecast at timescales of weeks to a few months ahead.

\section{Discussion}

Evidence from a variety of sources points to significant changes in the fire environment of SWWA during the current century. The trend to a drier climate has been reinforced by a series of low rainfall years that have resulted in declining streamflow and very low levels of moisture in the deep soil profile. 
This has increased the connectivity between vegetation types allowing fires to spread extensively across the landscape at an earlier time in the fire season than would have been the case several decades ago. Shorter and drier winters have reduced the opportunity for moisture uptake by large woody fuels and organic soils making them prone to ignition at an earlier time in the fire season.

The trend towards increased fire danger and lightning ignition activity during the spring months indicates a lengthening of the fire season, as does the later arrival of rain bearing cold fronts in the autumn. Fuels and vegetation now remain dry for several weeks longer in autumn than was normal during the 1980s. There is little evidence of a trend of increasing fire danger during the peak summer fire season, albeit that SWWA already experiences the highest mean number of January days $(\geq 12)$ when the FFDI is above the annual $90^{\text {th }}$ percentile value (Dowdy 2018).

The increased area burnt by large bushfires, most of which have been ignited by lightning, is consistent with previous research showing an inverse relationship between prescribed burning effort and area burnt by bushfire. Land use activities have made it difficult to undertake safe and costeffective prescribed burning at a landscape scale over significant parts of the public forest estate in SWWA leading to increased extent and connectivity of areas where fuels have accumulated for several decades. Addressing the backlog of areas in need of fuel reduction will require a clearly focussed effort, a substantial commitment of resources, and a preparedness to adapt work processes and operational guidance to meet changing circumstances. Potential changes in bushfire risk arising from land use activities need to be dealt with explicity as part of planning processes. Land managers can also exercise options to manage vegetation structure in ways that make it more resilient to fire, for example through silvicultural thinning to promote larger and more widely spaced trees.

Adapting to a changing fire environment has implications for all aspects of the fire management business, and a variety of new products and services are available to inform fire managers about temporal and spatial trends in components of the fire environment.

\section{References}

Bates BC, McCaw L, Dowdy AJ (in press) Exploratory analysis of lightning-ignited wildfires in the Warren Region, Western Australia. Journal of Environmental Management

Batini F (2016) The impact of bauxite mining on water yield. Paper presented at a workshop on managing forested catchments, Perth, 30 September 2016 (Institute of Foresters of Australia) Available at https://www.forestry.org.au/resources/managing-forested-catchments-threats-andopportunities. [Verified 29 June 2018]

Boer MM, Sadler RJ, Wittkuhn RS, McCaw WL, Grierson PF (2009) Long-term impacts of prescribed burning on regional extent and incidence of wildfires - evidence from 50 years of active fire management in SW Australian forests. Forest Ecology and Management 259, 132-142. http://dx.doi.org/10.1016/j.foreco.2009.10.005

Bureau of Meteorology (2018) Climate change and variability. http://www.bom.gov.au/climate/change/ [Verified 29 June 2018]

Burrows ND (1987) The Soil Dryness Index for use in fire control in the south-west of Western Australia. Technical Report No 17. (Department of Conservation and Land Management Western Australia, Perth).

Burrows N, McCaw L (2013) Prescribed burning in southwestern Australian forests. Frontiers in Ecology and Environment 11 (Online Issue 1): e25-e34.

Countryman CM (1966) The concept of fire environment. Fire Control Notes 27, 8-10.

Dowdy AJ (2018) Climatological variability of fire weather in Australia. Journal of Applied Meteorology and Climatology. doi: 10.1175/JAMC-D-17-0167.1 
Dowdy AJ, Pepper A (2018) Pyroconvection risk in Australia: climatological changes in atmospheric stability and surface fire weather conditions. Geophysical Research Letters 45, 2005-2013. doi: 10.1002/2017GL076654

Ferguson E (2016) Reframing rural fire management - report of the Special Inquiry into the January 2016 Waroona fire. (Government of Western Australia, Perth).

Hollis JJ, McCaw WL, Whitford KR, Cruz MG (2016) Woody fuel consumption by fires in open eucalypt forest in south-west Western Australia. In: Proceedings of the 5th International Fire Behaviour and Fuels Conference April 11-15, 2016, Melbourne, Australia. (International Association of Wildland Fire, Missoula, Montana, USA).

Indian Ocean Climate Initiative (2012) Western Australia's weather and climate: a synthesis of Indian Ocean Climate Initiative Stage 3 Research (Eds. B Bates, C Fredericksen, J Wormworth) (CSIRO and Bureau of Meteorology, Australia).

Jones D, Wang W, Fawcett R (2009) High-quality spatial climate datasets for Australia. Australian Meteorological Magazine 58, 233-248.

McArthur AG (1967) Fire behaviour in eucalypt forests. Forestry and Timber Bureau Leaflet 107. (Commonwealth Department of National Development, Canberra).

McCaw WL (2011) Characteristics of jarrah (Eucalyptus marginata) forests at Forestcheck monitoring sites in south-west Western Australia: stand structure, litter, woody debris, soil and foliar nutrients. Australian Forestry 74, 254-265.

McCaw L, Hanstrum B (2003) Fire environment of Mediterranean south-west Western Australia. In: 'Fire in ecosystems of south-west Western Australia: Impacts and management' (Eds. I Abbott, N Burrows) pp 87-106. (Backhuys Publishers, Leiden, The Netherlands).

Mount AB (1972) Derivation and testing of a soil dryness index using run-off data. Bulletin No 4 (Forestry Commission Tasmania, Hobart).

Peace M, McCaw L, Santos B, Kepert JD, Burrows N, Fawcett RJB (2017) Meteorological drivers of extreme fire behaviour during the Waroona bushfire, Western Australia, January 2016. Journal of Southern Hemisphere Earth Systems Science 67, 79-106. doi: 10.22499/3.6702.002

Smith A, Hafeez M, Rahman J, Baron-Hay S, Shipman D (2015) A new web based water information service leveraging the Australian Water Resources Assessment Modelling System [online]. In: '36th Hydrology and Water Resources Symposium: The art and science of water' pp 1276-1283. (Engineers Australia, Barton, ACT).

Sneeuwjagt RJ, Peet GB (1985) Forest fire behaviour tables for Western Australia. (Western Australian Department of Conservation and Land Management, Perth) 